\title{
Confucian Post-Liberalism
}

\author{
Robert Anthony CARLEO III*
}

\begin{abstract}
This paper reviews parallel attacks on the ethical basis of liberal principles from within and without that tradition, one the Confucian-Kantian perspective of contemporary philosopher Li Zehou 李澤厚 and the other the un-Kantian “post-liberalism” of John Gray. Both reject foundational claims regarding the universality of liberal values and principles while still affirming the universal value of those principles via their practical function in fostering for human flourishing. I point out that Gray's anti-foundationalist liberalism not only aligns with the Confucian elements of Li Zehou's theory, but may even be enriched by them.
\end{abstract}

Keywords: Li Zehou, Confucian Ethics, Confucian Political Philosophy, Liberalism, Post-Liberalism

\section{Konfucijanski postliberalizem}

\section{Izvleček}

Pričujoči članek vsebuje kritiko etične osnove liberalnih principov $z$ dveh vidikov: od znotraj in od zunaj. Prvi obravnava konfucijansko-kantovsko perspektivo sodobnega filozofa Li Zehouja 李澤厚, drugi pa ne-kantovski »postliberalizem« Johna Graya. Tisto, kar je skupno obema, je negacija osnovne ideje liberalnih vrednot in principov ter poudarjanje univerzalnih vrednot tistih načel, ki preko svojih praktičnih funkcij podpirajo družbene strukture, ki krepijo človeško blagostanje. Pri tem avtor poudari, da slednja teorija ni samo skladna s konfucijanskimi elementi prve, temveč lahko te tudi obogati.

Ključne besede: Li Zehou, konfucijanska etika, konfucijanska politična filozofija, liberalizem, postliberalizem

\section{Introduction}

A central issue in political theory today is whether and how it is possible to construct and guide modern-most often understood as liberal, individualist, egalitarian, and capitalist-social institutions in ways that reflect and are supported

* $\quad$ Robert Anthony CARLEO III, a PhD candidate in Philosophy at the Chinese University of Hong Kong.

Email address: racarleo@qq.com

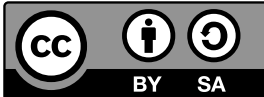


by the more traditional and particular values of the communities they govern. The demand for such cultural localism or particularization follows from the value of self-determination, collective and personal, often invoked in justification of modern liberal institutions - that people ought to (at least be able to) pursue lives and ways of life that they see as (most) worthwhile. Modern liberal ideology in this sense demands cultural particularity both practically and normatively: the functioning and legitimacy of social and political institutions require (at least a certain degree of) endorsement by those participating in and governed by them, and this can take place only in terms of values these citizens themselves hold.

Yet while the value of self-determination seems to demand cultural particularism, the claims of modern liberal ideology are generally universalist, and the institutional norms they promote-natural human rights, freedoms, and the values of self-determination and equality - construed as objective goods. They are goods in virtue of constituting the very terms on which (fair) self-determination is possible. Thus, particular cultural traditions can and should, or must, be expressed through modern liberal values and institutions, and these values and institutions are not to be breached in their expression. To alter these institutions in the name of particular traditions is then merely to compromise them, and so compromise the very terms of fair self-determination.

Thus, liberalism's promotion of individualist democratic and capitalist institutions is axiologically founded on individual and collective self-determination, yet promoting these institutions and values themselves requires heteronomously altering traditional cultural values and social structures that do not align with, and thus must to some extent be replaced by, democratic and capitalist values. There seems to be tension or conflict, then, internal to the theory and practice of liberal principles and institutions in their claim to promote fair self-determination. This tension is particularly acute in cultures for which the terms of modern liberal institutions and their underlying values are not native, but which in modernizing have formally adopted liberal institutions and norms as well as (partially) absorbed corresponding democratic and capitalist values. Sungmoon Kim, for example, identifies this difficulty in liberal democratic South Korea, whose culture remains substantively Confucian in character, if not in name (Kim 2014, Ch. 9; 2016, Ch. 3 and 4). Liberalism might thus be seen as promoting an ideology and set of institutions that stand opposed to cultural particularity and true self-determination, and which prove hegemonic to particular local cultural systems, traditions, and values.

Liberalism, then, finds itself in a somewhat awkward position. Its defenders claim that it allows for self-determination through universal principles or prescriptions, and sometimes admit that it is itself a culturally particular view and does not aspire to universalism. Its detractors say that it hegemonizes other valuable ways of 
life, and sometimes even that in doing so it replaces these with an impoverished ideology, largely empty of values. But whether all, some, or none of these views are correct, the fact remains that many societies now operate-socially, politically, and legally - through liberal democratic and capitalist systems yet retain substantive traditional values at odds with the liberal values on which the functioning of these systems was designed. What to make of this and what is to be done about it are particularly poignant questions for comparative political philosophy, and they have received much attention in contemporary Confucian discourse, wherein the issue is most often posed as: What are traditional Confucian values to do in the face of modernization? As I have attempted to show above, an equally interesting question is: What is liberal theory to do in the face of Confucian values? Our answers depend on how we conceive of liberalism.

Below I review parallel attacks on the ethical basis of liberal principles from within and without that tradition, one the Confucian-Kantian perspective of contemporary philosopher Li Zehou 李澤厚 and the other the non-Kantian "post-liberalism" of John Gray, both of which reject foundational claims regarding the universality of liberal values and principles but which affirm the universal value of those principles via their practical function in supporting social structures that foster for human flourishing. Gray's advocacy of post-liberalism is exceptional as a critique of liberal doctrine that is philosophically rather than politically or ideologically motivated, and even largely driven by liberal rather than anti-liberal commitments. As we will see, Gray, like Li, finds the diverse formulations of liberal theory proposed by liberal theorists incoherent or unpersuasive, and ultimately aims to affirm liberal principles on more solid grounds. I point out that his arguments not only align with the Confucian elements of Li Zehou's theory but may even be enriched by them.

\section{What's Wrong with Liberalism?}

Liberalism often presents itself as a universal doctrine, espousing objective principles of liberty or justice by which states ought to govern. This is, for example, how J. S. Mill presents his arguments in On Liberty. It more dramatically forms the core of Kantian arguments as epitomized, for example, in Kant's various formulations of the categorical imperative, which is carried forward in contemporary successors such as John Rawls in A Theory of Justice (1999) and especially Ronald Dworkin (2011), who likewise grounds liberal practices in objective ethical, moral, and political principles. These principles are understood as universally applicable to all people: since their normative force is generated by a generic conception of the human being, they have moral grip on each of us simply by virtue of our humanity. As Francis Fukuyama puts it, Kantian-Dworkinian normativity, for contemporary 
liberals, "etches a bright red line around the whole of the human race" (Fukuyama 2002, 150). Born from Christian and Kantian notions, modern liberalism affirms principles of government as timeless and universal morals of humanity itself.

Li Zehou denounces this dimension of liberalism, arguing that modern liberal principles and values are better understood as social norms historically particular to modern liberal culture. They are morals or rational imperatives produced by peculiarly modern forms of reason, not derived from "reason" as such: "rational principles or reason itself come from the living existence of humankind and are not $a$ priori" (Li 2016, 1077). Li's rejection of Kant's a priori or pure reason aligns with a trend in Kantian ethical theory abandoning the transcendental or metaphysical dimensions of Kant's thought, but is distinct from the corresponding tendency to shift from grounding morality in the faculty of reason toward a defence of the normative force of moral reasons (see, for example, Scanlon 2011). These views replace the universal and absolute faculty of pure reason with an equally ahistorical rational a priori moral principle, shifting the grounds of moral objectivity from the faculty of pure reason to a rational capacity to evaluate concrete reasons, governed by some absolute and unchanging moral principle. Li Zehou, in contrast, rejects the possibility of objective moral principle independent of concrete historical conditions altogether.

A particularly important element of this difference between Li Zehou's historicist Kantian theory and these forms of contemporary Kantianism is that while they follow Kant in formulating the a priori value of humans as ends as a rational and stateable principle of equality, Li reinterprets the principle of humans as ends as historically contingent, and decidedly not as a universal a priori truth ( $\mathrm{Li} 2011$, 23-24; 2016, 1131; cf. Carleo 2020). On this basis, Li opposes "individual freedom or ... 'justice' being prioritized as supreme a priori or transcendental rational principles" as in Kant and Rawls (Li 2016, 1086). As historical products of concrete culture, the application of these principles should be evaluated in context and adjusted accordingly. They cannot serve as universal moral or political standards for all cultures.

These standards cannot be universal because human psychology and relations are not generic. Moral norms, in Li's view, are not only applied to concrete human situations, they also arise from them. The emotion and reason that constitute moral psychology are products of concrete, situated human experience and learning, and developed historically within human culture. As norms governing concrete human relations through human psychology, moral imperatives thus shift. (As an empirical observation, this is difficult to dispute; normatively, it presents a much-disputed form of moral relativity that is often theoretically formulated in ways that are intuitively and philosophically unsatisfactory. Li rejects such forms of relativism and attempts to formulate a more persuasive view that establishes 
an objective basis for moral relativity, which we return to below.) In contrast, the reliance on generic conceptions of rational personhood in Kant, Rawls, Dworkin, and others in attempting to establish normative principles with universal grip, and Mill's reliance on a combination of teleological development of individuality and a notoriously dubious form of welfarism, all rest on axiological assumptions that are not themselves, empirically speaking, universal, but rather came to prevalence historically with the rise of modern liberalism, rationalism, and individualism. Li's position is attractive because it recognizes the historical particularity of that axiology while affirming its normative force for modern societies.

That liberal principles are not universally rationally deducible in the manner that much liberal theory attempts to establish is a criticism Li shares with John Gray:

In general, it is one of the oldest aspirations of philosophers to formulate criteria or legislate norms of deliberative rationality which will be universal and context-independent in that they reflect the natural necessities of man's life, and which (unlike the rules of inference of formal logic) will impose substantive restrictions on the conduct of practical reasoning. Notoriously, this perennial aspiration is open to the objection that the task of distinguishing between what is generic and what is specific in human life, between what is essential and what is accidental, between nature and convention, is (logically, or as a matter of fact) impossible to bring off. (Gray 1989, 34)

Gray's formulation of the criticism here impugns Rawls's reliance on generic goods, which Rawls calls primary social goods, as the basis for deriving principles of justice. These generic goods rely on a generic conception of human nature- the kind of Aristotelian view that liberals such as Rawls and Dworkin share with critics such as Charles Taylor (Taylor 1985; cf. Kymlicka 1989, 894-96) and Alastair MacIntyre (1984). Gray contends that this view of human nature and correspondingly Rawls's (or any) list of primary social goods are culturally dependent, ${ }^{1}$ and argues—as Li Zehou does as well- "that human nature is always entirely constituted by a nexus of historically variant, culturally specific and alterable social relations" (Gray 1989, 35). Since people's ways of life are therefore products of the circumstances and relations, along with the biological character, they are born into, therefore, "no conception of the good life can be privileged over others on the grounds that it is more deeply founded in man's nature" (Gray

1 "Rawls gives the derivation of the principles of justice from the circumstances of the original position an appearance of plausibility only by building into the deliberative rationality of the contractors' normative specifications (such as that embodied in the Aristotelian principle) whose culture-dependency is patent." (Gray 1989, 34) 
1989, 35). While this does not quite indict the Rawlsian view-since Rawls argues not that a particular conception of the good life is found in human nature, but that the primary social goods are generic because they are fundamental to the pursuit of any (individual's) conception of the good life-it points toward a more fundamental objection endorsed by Li Zehou's views. Since individual pursuit of the good life is informed and partly determined by the cultural and institutional conditions of society, the conditions for that pursuit will also shift. There are thus no unchangeable or generic primary goods; rather, all primary goods (as the conditions for pursuit of the good life) will be particular to the concrete conditions of actual societies, including economic and political structures, cultural values, and social norms.

Although Gray, like Li, is dissatisfied with the theoretical incoherence of liberal doctrine, and both decry the dogmatic and axiomatic way in which liberal values and principles are often invoked, Gray remains deeply committed to liberal practices. Li likewise celebrates the value of liberal principles and modernization generally in releasing people from more oppressive traditional social structures. He thus rejects the universal and a priori nature of the principle of humans as ends, but affirms that same principle as a historically particular value appropriate to contemporary society.

Especially in terms of ethics, we cannot talk about society without considering the individual, and thus liberalism has made important contributions to this area of human history. (Li 2016, 1123)

Clearly, many principles of liberalism do not arise from the theoretical suppositions of Kant and Rawls, but rather from social life and the experience of humankind. Kant and others abstract this as the universal certainty of a priori reason, innate human rights, and the atomic individual. Even though such a standpoint is untenable, these ideas hugely elevate the position of humans and encourage people to work hard to realize certain ideals, which has positive effects on history and in actual life. (ibid., 1121)

[L]iberal individual freedom and value neutrality ... are in fact pressing necessities for many nations in breaking free from the economic and political manifestations of their traditional societies (such as primitive tribalism, slavery, and serfdom, as well as religious and cultural autocracy and privilege). Value neutrality, prioritization of rights, and individual freedom are ... strongly needed for social development by certain countries and regions. (ibid., 1128) 
That is, the value or authority of liberal principles is not universal but pragmatic and particular, based in its function within social systems in improving the conditions of individual and collective human life.

Concepts of justice associated with liberalism are the basic principles of modern social morals. People follow them not because they are the products of a particular thinker, but rather because these notions have the support of economic forces. These economic forces have taken abstractly conceived concepts like 'the atomic individual' and 'natural human rights' and seemingly actualized them, making the independent individual, the social contract, and public reason increasingly part of institutional order, behavioral norms, and moral standards. (Li 2016, 1085)

Li further argues, on the basis of the beneficial function of liberal norms in modern society, that while many communitarian arguments share his dissatisfaction with liberalism's claims to universality (so that, "Theoretically speaking, communitarianism makes a good point"), on a practical level communitarians merely obstruct the helpful, forward-looking nature of the substantive guides for contemporary China that liberalism offers. Because communitarian views are merely critical and theoretical, adopting them "may easily come to serve as a basis for regression, effacing the individual and returning to a previous era" $(\mathrm{Li} 2011,28)$.

Humans as ends, taken on a pragmatic and historicist basis, presents an imperative to develop social and political norms and institutions that foster individual pursuit of interests and prosperity and thereby also associative flourishing. This shifts social norms from a pre-modern orientation in which the individual is seen as serving the group (collective or common interests) to a modern orientation of norms and institutions serving the individual and individual interests (or common interests reconceived as collective interests of disparate individuals, rather than interests of a shared group identity) (ibid., 32). This modern individualism and the norms protecting and promoting it "are important aspects of the future prospects of humankind," and thus, "The theory of self in my own ethics is a form of historicism that sees movement from the 'greater self' (dawo 大我) to the 'smaller self' (xiaowo 小我)"(Li 2017, §4).

Li here does not merely affirm liberalism on historicist grounds (indeed, this would not differ significantly from later Rawls). He revises (or in his words, "transcends") liberalism to embrace emotions and relations. Liberalism takes individualism too far in attempting to rationally derive normative principles from a conception of transcendental or unencumbered individuals, and Li's ethics in response emphasizes “relationism" (guanxi zhuyi 關係主義) and the importance of emotions as feelings of human interconnection (Li 2016, 1080). The moral importance of 
emotions and relations are core tenets of Li Zehou's ethical theory, which he derives from classical Confucianism and places in opposition to liberalism's emphasis on reason and individualism. In promoting his ethics, $\mathrm{Li}$ is on these issues a trenchant critic of liberal ethical theory. Yet he gives priority to liberal principles because his historical outlook finds them to be necessary, beneficial, or desirable as social and political norms for contemporary Chinese society.

$\mathrm{Li}$ thus finds individualism to support human flourishing as it is increasingly embraced across developing societies, as evidenced by the fact that "these new social morals seem to generally win out and continue to break into diverse regions, peoples, and cultures" ( $\mathrm{Li} 2011,24)$, and believes a properly redressed individualism, a relationally and emotionally understood valuing of the individual, will better support human flourishing. Li affirms the spread of liberal individualism and its liberating capitalist and democratic institutions, which include human rights, freedoms, and political neutrality, to be a moral imperative for modern society. This makes Li something of a liberal, in his own way:

The liberalism that I endorse (in which the totality exists for the individual and individual rights have priority) is an aspect of my historicism. That is, it is a requirement or product of historical development of a certain period or stage. In this way liberalism is part of historicism, and history does not end with capitalist society and liberalism. This both emphasizes [liberal] justice as well as takes the "emotional cosmology" of [my] idea that "harmony is higher than justice" as regulative in order to move toward a more ideal future. This transcends liberalism. (Li 2016, 1136)

This is the form of 'liberalism' that I advocate: promoting modern concepts as the foundation for erecting future human psychology, and through education gradually both preserving and reforming tradition's deep emotio-rational structures. (Li 2018, 224)

So how does he marry his affirmation of liberal principles to his ardent promotion of Confucian morality, and especially its emphasis on relations and emotions, in opposition to the emphasis on reason and individualism in liberal moral and ethical theory?

In endorsing the value and authority of liberal principles for Chinese society, Li argues that traditional Chinese morality is necessary to redressing liberalism's theoretical and practical problems, especially in developing the application of liberal principles for Chinese society. 
[L]iberalism such as that of Rawls' notions of "the difference principle" (A Theory of Justice), "overlapping consensus" (Political Liberalism), and "the priority of the right over the good" is exactly what China needs today. But China should also be careful to avoid being overwhelmed by immensely rational economic and political mechanisms. This is the importance of the corrective value of traditional Chinese notions such as "the way begins in emotions" and guanxi-ist relationality, which can serve as the "regulative and properly constitutive" principle for these rational mechanisms. (Li 2016, 1139)

The conclusion of repeated disputes over the last century is quite clear: modern Western rule of law must be adopted, and traditional ritual and law's use of ordered relations in place of law, or of interpersonal emotions in place of reason, must be abandoned.... However, since the gradually formed ideas and customs, and emotio-rational structure, of society cannot be simply and suddenly done away with, conceptions of modern rule of law exhibit certain conflict with the actuality of modern Chinese life ... (Li 2018, 206)

Independent liberal principles and traditional Confucian morals should be seen as distinct but also compatible types of morality.

Although I do not agree with foundationalist liberal theories, from notions of natural human rights to the veil of ignorance, I nevertheless see great value in the modern morals and laws proposed and advocated by liberalism that take the individual as fundamental. I also emphasize the special importance of establishing these within China's shamanistic historical tradition [See Li Zehou 2018], and therefore argue that we must first differentiate between the two types of morals (traditional religious morals and modern social morals). (Li 2011, 29)

Li offers his own theory as a means of differentiating, and then reconnecting, these two types of morals.

\section{Li Zehou's Theory of Two Morals}

Li Zehou's theory of two morals (liang de lun 两德論) advocates the distinction of modern social morals (xiandai shehuixing daode 现代社會性道德) from traditional religious morals (chuantong zongjiaoxing daode 傳統宗教性道德). Li 
defines social morals as "the common principles, norms, order, values, and modes of behavior on which the maintenance of modern life relies, and include liberty, equality, human rights, democracy, and so on"; religious morals, in contrast, consist in beliefs and emotions "concerning the individual's ultimate concern and the ideal of placing oneself at ease and establishing one's fate" (Li 2018, 209). The former constitute a normative ethics, whereas the latter have to do with personal virtue. $\mathrm{Li}$ advocates modern social morals more or less equivalent to liberal norms-ethical norms that "strive for liberty, equality, and human rights" — and traditional religious morals constituted by Confucian commitments that value relations of "familial compassion, caring, and concern for others" (ibid.).

Li's distinction is largely equivalent to Rawls's differentiation of the principles of justice, as the right (or political norms governing the basic structure of society), from comprehensive doctrines of the good. Li also prioritizes modern social morals in a manner comparable to the priority that Rawls grants to the principles of justice, making them indefeasible by considerations of traditional religious morals. Moreover, "Like Rawls' position, my prioritization of this distinction attempts to avoid the so-called clash of tradition and modernization" (Li 2016, 1133). That is, Li's distinction aims to reconcile the two, to establish a stable relation between liberal principles and traditional values.

Yet while Li's two morals parallel Rawls, the grounds of his distinction and the relation he establishes between them differ from Rawls in important ways. According to $\mathrm{Li}$, originally the former was enveloped within, or determined by, the latter, so that traditional Confucian religious ethics subsumed social morals. Pre-modern Chinese political norms and institutions combined Confucianism with (traditional Chinese) Legalism, resulting in a "tripartite unity of religion, politics, and ethics" that led social morals to be heavily determined by overly hierarchical and often oppressive forms of human relations. Li believes that China has not entirely left this behind, but ought to, and intends his theory of two morals to deconstruct this tripartite unity. In line with his emphasis on historical particularity, Li's argument for prioritizing liberal principles is thus fittingly historical: traditional Chinese norms and institutions were relatively more oppressive due to an over-reliance on existing concrete forms of human relations, so prioritizing rational liberal principles helps liberate subjects from such oppression and promote conditions of human flourishing through rational and individualist rule of law $(\mathrm{Li} \mathrm{2018,210).}$ The corresponding institutions of rights and freedoms are relative goods, and their relative benefits are the grounds for affirming liberal principles in modern society.

Moreover, while modern social morals are distinct from traditional religious morals, they cannot be fully independent of them ( $\mathrm{Li} \mathrm{2011,31).} \mathrm{Li} \mathrm{emphasizes} \mathrm{the}$ need for this reconnection (once they are differentiated), since "The complete entanglement of the two kinds of morality penetrates groups and individuals, 
which is both necessary and natural" ( $\operatorname{Li} 2011,32)$. In terms of the form of this reconnection, he advocates giving traditional religious morals- that is, the deep structures of Confucian morality prevalent in Chinese society-a "regulative and properly constitutive" (fandao he shidang goujian 範導與適當構建) function in relation to modern social morals. ${ }^{2}$ Whereas Rawls maintains the independence and inviolability of the right in relation to the good, denying comprehensive doctrines any constitutive role in relation to political conceptions of the right, $\mathrm{Li}$ proposes substantive connections between them, making religious morals both "properly" - that is, in a limited capacity — constitutive of social morals and also allowing traditional morals to shape the application of liberal principles within society.

These are relatively abstract statements. Li gives a more concrete and illustrative sense of what he means in arguing that China must "absorb modern liberalism as a criterion for contemporary legislation" ( $\mathrm{Li} 2018,209$ ) while also advocating that legal suit should be a final recourse in China, following more personal forms of mediation, in line with a Confucian emphasis on harmonious personal relations. He cites China's “people's mediation system” (renmin tiaojie zhidu 人民調解制度) and local residents committees (jumin weiyuanhui 居民委員會) as preliminary models for how this might work (Li 2016, 1110, 1134; 2018, 202-10, 226-27, 249-50; cf. 2008, 46).

Li describes traditional culture's "regulative and properly constitutive" but not determinative role in relation to basic rights as the "permeation, influence, and functioning of substantive justice within formal justice" (Li 2016, 1134), and refers to its practice as “political art” or “the art of government” (zhengzhi yishu 政治藝術) (ibid., 1091, 1133). It is equivalent to the art of assessing "proper measure" (du 度) in navigating concrete situations, and to the traditional Confucian concept of "flexibility" (quan 權), and also involves the skill of "conforming to emotions as well as reason" (heli heqing 合理合情) rather than inflexible application of normative principles (Li 2012, 107; 2016, 1091-92, 1119). ${ }^{3}$ Here Li emphasizes the integration of emotion with rational judgment:

To borrow a phrase from Chairman Mao, there is no love or hate without cause or reason. Emotional aspects of human existence can certainly be described and examined through rational analysis. At the same time, through factual description and explanation, emotions can not only affect

2 While $\mathrm{Li}$ sometimes denies the constitutive function of religious morals in relation to social morals entirely (i.e. Li 2018, 210; 2011, 32), he seems to mean this as a declaration of the formal independence of the latter from the former, in terms of its priority.

3 "Thus, the art of grasping 'proper measure' in recognizing the complex relationship between these two kinds of morals and in concrete analysis of particular situations is shown clearly to be of special importance." (Li 2011,32) 
but also even convince people of things. That is to say, emotions have causes or reasons, and "conformance" to them also has a certain rationally understandable pattern.... Confucius talked about ritual throughout his life, and yet while he repeatedly criticized Guan Zhong 管仲 for "not knowing ritual", Confucius nevertheless lauded his overall virtue (ren 仁). This is a classic illustration of how we might carry out "flexibility" (not adhering blindly to the established rules of ritual) through "conformance with emotions". Here we find that reason is ... connected with patterns of emotionality, as well. (Li 2016, 1119)

Thus, Li advocates a Confucian sense of morality or virtue that involves not merely the governance of reason over emotions in the sense of following rational rules of conduct, but also responsiveness to emotions in (rational) moral evaluation. The moral guidance of rational principles has to adapt to the particular values and emotional relations that constitute a moral situation.

In this sense, $\mathrm{Li}$ establishes a moral need to be responsive to the concrete emotional relations of substantively Confucian societies in applying rational principles of modern social morals (as liberal norms). Li's theory of two morals in this way embraces and promotes the deep structures of Confucianism, which substantively shape the relations of Confucian society, and which can guide proactive social policies exhibiting "concern for the people"; but he also limits their role to directing action on the level of individual decision-making, "which must be differentiated from the 'social morals' (public virtue) to which people are to commonly adhere" (Li 2018, 224; cf. 2011, 26). In this way the personal values and beliefs of traditional religious morals have a regulative function in the application of modern social morals, but are only properly constitutive, that is, not constitutive in a manner able to themselves revise or re-determine the content of modern social morals.

Here we note two roles that Confucianism takes up in Li's theory: firstly, as the deep structures of traditional Chinese values and beliefs that continue to constitute the moral character of Chinese culture, and secondly, as part of his own moral theory, which repurposes Confucian moral teachings to serve as a means of affirming both traditional Chinese culture and modern liberal norms. The historicism identified above as the grounds for affirming liberal principles for modern society itself requires a moral foundation, and $\mathrm{Li}$ provides this through the moral theory he develops from classical Confucian teachings. Herein, the ultimate axiological foundation is the continuous extension of human existence (renlei de shengcun yanxu 人類的生存延續) (as communities and societies).

$\mathrm{Li}$ argues that there is an absolute grounding for substantive moral judgment in the historical process of the "sedimentation" (jidian 積澱) of human knowledge, 
culture, and reason. Morality and reason are regulated by the conditions of human progress wherein goodness and badness can be objectively determined ( $\mathrm{Li}$ 2016, 1120-21). Li thus writes, "Ethics is attendant on history" (Li 2011, 6), and denounces relativism, despite endorsing the relativity of good and evil and right and wrong. The grounds for this absoluteness lie in the concrete needs of humankind-what Li refers to as "the extension of the life of the integrated totality (zongti 總體) of humankind past, present, and future” (ibid., 8). While the particular norms of specific societies may differ, morality retains ultimate grounding in the interests of greater humanity. Such grounding allows specific moral principles to be absolute imperatives without requiring the existence of universal and eternally applicable prescriptions or proscriptions.

$\mathrm{Li}$ grounds the importance of proper measure in the need to adapt to the constantly changing historical conditions in which humans live, which he describes as the "activity of continuously grasping precisely what is best as it constantly changes" and which "thereby allows the community and the individual to continuously expand their living existence" ( $\mathrm{Li}$ 2018, 268-69). Li identifies these views and values with the traditional beliefs and values of Chinese culture, and specifically with their embrace of the constant processes of change through which the continuous generativity of the world and humanity-of their production and reproduction (shengsheng 生生)—takes place. It is precisely this value on which Li's historicism affirms both traditional and modern social morals. Li writes:

I am a historicist. I see all of ethics and morals, including justice, as serving the continuous extension of human existence ... (as communities and societies) and understand justice as coming not from rational agreement between individuals but rather from the concrete historical circumstances of communal existence, including shared emotional experience $(\mathrm{Li}$ 2016, 1076).

$\mathrm{Li}$ argues that Confucianism prioritizes this value of production and reproduction, which occurs through diverse forms of natural and social human interrelation, which in turn produce moral norms and duties (ibid., 1096). These generative, reproductive relations are unequal (in various senses) and emotional. They are also structured by rational norms and are the source of meaning and value in human life (ibid.).

In this way, his ethical theory combines the grounds of traditional Chinese morals and modern liberal morals in his own interpretation of classical Confucian moral theory, which emphasizes morality's complex integration of emotion and reason and the fundamental role of the concrete situatedness of human experience. 
I view the formation or origin of the principles of justice through classical Confucian ideas such as that "rituals are generated from emotionality," "the way begins in emotionality," and "rituals are such due to human emotionality," all of which are found among the Guodian bamboo slips. (Li 2016, 1076)

In my reading of Li's ethics and political philosophy, then, humanity's concrete, continuous production and reproduction is the sole axiological foundation-the single normative assumption and source of normativity. That is to say, $\mathrm{Li}$ derives the moral force of his ethics from the value of human flourishing, in its continuously shifting historically relative forms.

Since production and reproduction consist in or occur only through concrete relations, the human values grounded in them are always situated and the substantive norms they generate always situationally particular; correspondingly, since particular human values are grounded in the more fundamental value of life producing life, their relativity takes on an absoluteness within these concrete empirical bounds. Thus, for Li, relativity is not relativism, so to speak. Li creates space for both relativity and objectivity by bounding the absolute value of human production and reproduction in the concrete forms of human relations through which it arises. This grounds liberal principles in a simpler and more stable axiology, with the help of historicism, than the more abstract formulations of, say, Rawlsian constructivism, or even the axiological (quasi-religious) assumptions of, say, Dworkinian human dignity. It also affirms these principles for modern Chinese society without the need to replace deeply embedded traditional values - the substantive moral character of Chinese society - with an imported value system. Li rather allows for Confucian morality to serve as the basis for affirming both traditional religious (comprehensive) morals and modern (liberal) social morals.

$\mathrm{Li}$ thus overcomes liberalism's internal contradiction-requiring hegemony in the name of self-determination-in two ways. He manages to endorse liberal principles without relying on foundationalist presumption of the value of liberty or freedom, as individual and collective self-determination, and he achieves a means of endorsing modern liberal social and political institutions in terms of values that Chinese citizens themselves hold. In the former, he avoids certain common but philosophically unstable axiological presumptions. In the latter he achieves a valuable means of connecting modern institutions to traditional values for Chinese societies.

\section{Post-Liberalism}

Li Zehou's affirmation of liberal principles, then, is embedded within — and even arrived at through - a deep critique of the liberal moral views through which 
these principles arose and on which they continue to rest, however flimsy they may be in those forms. Li presents his own Confucian moral theory, on which he affirms liberal principles for modern society, in opposition to liberal moral theory, rejecting liberalism's overemphasis on reason and individualism and arguing for the more substantive and even foundational role of emotions and concrete interrelation present in classical Confucian morality. The production and reproduction of human flourishing through these relations are the ultimate grounds of this morality.

Concrete production and reproduction of human flourishing is also the basis on which John Gray ultimately affirms a non-foundationalist version of liberalism, which he refers to as "post-liberalism". The post-liberal denies liberal orders' "universal or apodictic authority", in contrast to the foundationalism of most or all liberal political philosophy (Gray 1993, 284). He sees liberal doctrines as futile attempts to establish the universal authority of culturally and historically particular liberal practices (ibid., 246), and although he recognizes that some contemporary liberals merely aim at articulating principles of liberal democratic society and claim no such universalism, including Joel Feinberg, Richard Flathman, and Joseph Raz as well as Rawls in his later work (Gray 1989, 266n35; 1993, 243, 246), ${ }^{4}$ Gray rejects even these views as doctrinal, arguing that their failure to provide sound philosophical grounds for liberal principles evidences the impossibility of the task.

Gray identifies and pronounces the doctrinal death of four constitutive elements of liberalism: universalism, individualism, egalitarianism and meliorism (Gray 1993, 284-313), and argues that following this doctrinal death, what remains alive of liberalism "is the historic inheritance ... of a civil society whose institutions protect liberty and permit civil peace" (ibid., 284). Gray then re-affirms all four constitutive features of liberal doctrine, but "in a contextual form" as qualities of civil society (ibid., 319-20). It is civil society, the institutions and principles of which can take various and unfixed forms, that "both history and theory show to be the precondition of prosperity and liberty in the modern world" (ibid., 246). On the value of prosperity and liberty, Gray affirms the value of liberal institutions that serve as their precondition.

Gray, moreover, rejects presumption of —or what he calls "presumptivism" aboutthe value of liberty, arguing that it constitutes a widespread weakness of liberal theory. Instead, the value of liberty is, like other liberal principles and institutions, derivative of its role as an empirical condition of human flourishing. Gray

$4 \quad$ Gray references specifically Feinberg's The Moral Limits of the Criminal Law (Oxford University Press, 1984), Flathman's The Philosophy and Politics of Freedom (University of Chicago Press, 1987), and Raz's The Morality of Freedom (Oxford University Press, 1988). 
correspondingly rejects definitional or conceptual analysis of freedom per se, instead presenting himself as a theorist of concrete and historical practices of liberty.

Freedom is on this account constituted by the practices of civil society, which it is the task of the theorist to illuminate. Any such understanding of the practice of liberty is bound to be an historical understanding-one that conceives of civil society as an historical artefact-but one that, in the context of the condition of late modernity (or early post-modernity) offers the best, if not the only prospect for the reproduction of civilized life. (Gray 1993, 318-19, emphasis in original)

The practice of liberty animates civil society (ibid., 284), and it is only through civil society that "a modern civilization can reproduce itself" (ibid., 246). Avoiding axiological (and in his view, axiomatic) reliance on a presumed value of liberty and of liberal principles and institutions as they developed in historically particular Western tradition, Gray rests his endorsement of these on their empirical role as conditions of human flourishing in modern society.

Like Li Zehou, then, Gray rejects liberal theory but then reaffirms liberal principles and institutions on the grounds of their concrete function in promoting continuous human flourishing in modern society. He rejects the a priori normative force of these principles, arguing that instead they instead they should be "contextualized and historicized as features of late modern (or early post-modern) societies and polities" (ibid., 284), and correspondingly ridicules the common presumption that political and social institutions as they developed in the West constitute ideal universal models. ${ }^{5}$ Yet he finds alternative grounds for the normative force of liberal principles and institutions in their pragmatic effectiveness in producing and reproducing human flourishing. Moreover, since liberal civil society seems to, empirically speaking, possess universal value and even necessity in (best) fostering human flourishing through protecting free and secure personal and associational pursuit of interests, "all, or nearly all forms of government that allow for commodious living will in the foreseeable future be ones that shelter the institutions of civil society" (ibid.). Thus, also in line with Li, Gray affirms (non-doctrinal) universalism and (non-teleological) perfectionism: it is liberal civil society, and not liberal democracy, that will ultimately win over human allegiances across cultures and regimes (ibid., 246).

5 There is no universal ideal form of government, since regimes of many forms may protect the relevant institutions of civil society, as "a society in which most institutions, though protected by law, are independent of the state", with an emphasis on institutions that foster free and secure personal and associational pursuit of interests, such as "private property and contractual liberty under rule of law" (Gray 1993, 246). 
Gray's post-liberal affirmation of liberal principles is achieved in slightly different terms than Li Zehou's, resting heavily on empirical pluralism rather than an emphasis on emotions and concrete relations: "a liberal civil society is the best one for cultures, such as all or virtually all contemporary cultures, which harbor a diversity of incommensurable conceptions of the good" (ibid., 284). Yet as seen above, Gray also relies heavily on relationality in affirming this pluralism, as where he writes that "human nature is always entirely constituted by a nexus of historically variant, culturally specific and alterable social relations" and that therefore "the forms of man's life are the creations of his own practice, constrained only by the facts of his constitution and by the circumstances he inherits from his forebears" (Gray 1989, 35).

While Gray, like other liberals, tends to avoid discussion of the moral importance of emotions, this may be implicit to, or at least necessarily implied by, his theory as well. Emotions are important, not only as part of these facts of human constitution and circumstance, but also in being essential to any concrete measurement of human flourishing. This is a point generally emphasized in Confucian teachings but often obscured in the rationalist discourse favoured by many contemporary Anglo-American theorists, who subsume the moral importance of emotions into moral "reasons," which are constituted by factual conditions of human circumstance (including the emotional elements therein), and who describe the affective force of these reasons in accounting for moral motivation as, for example, their (rational) "moral importance" (i.e. Parfit 2002, 310-12; Scanlon 2014, 5-7, 86-90).

The dangers of a purely rationalistic reliance on moral principles, without valuing people's emotions, is a major theme developed from the Confucian classics and emphasized by late-imperial Chinese Confucian thought. Qing-dynasty Confucian scholar Dai Zhen writes, for example, that disregard for human emotions in dealing with affairs leads to harming individuals, and even the state and all under heaven, because those referencing moral principles separate from human emotions and desires then elevate arbitrarily determined, abstract principles above concrete considerations of human suffering. This fails to recognize the importance of that suffering in determining what is right and wrong:

When they see people crying out from hunger and cold, men and women wailing because of the injustice done to them, and even those on the verge of death still desperately hoping to live, they claim these are no more than human desires, point blankly to a thing [i.e., pseudo moral principle] devoid of feelings and desires, and claim that this is the original state of heavenly principle, preserved in their heart-minds. (Dai 1961, $\S 40 ;$ Chin and Freeman 1990, 165) 
Dai Zhen advocates an interpretation of classical Confucian teachings that embeds moral principles in the concrete patterns of human interrelation, the emotional dimensions of which must be studied in order to determine right and wrong, which are themselves axiologically grounded in the fundamental value of production and reproduction (shengsheng 生生) in human life. This pointed criticism of rationalism not only aligns with Li Zehou's arguments, but also importantly buttresses post-liberalism's anti-foundationalism more generally.

Thus, Li Zehou's rejection of the doctrinal universalism of foundationalist liberal theories accompanies a Confucian affirmation of liberal principles on "post-liberal" and Confucian grounds. Ultimately, post-liberalism - at least in East Asia, but likely beyond - may prove not only aligned with but, in its most philosophically robust form, also largely substantively indistinguishable from such a version of Confucian liberalism. Or viewed in the opposite direction, civil society governed by liberal principles may best allow, at least today, for a prevailing of the Confucian Way.

\section{References}

Chin, Ann-Ping, and Mansfield Freeman. 1990. Tai Chen on Mencius: Explorations in Words and Meaning. New Haven and London: Yale University Press.

Dai, Zhen 戴震. 1961. Mengzi ziyi shuzheng 孟子字義疏證 (Evidential Commentary on the Meanings of Terms in the Mengzi). Beijing: Zhonghua shuju.

Dworkin, Ronald. 2011. Justice for Hedgehogs. Cambridge, MA: The Belknap Press of Harvard University Press.

Feinberg, Joel. 1984. The Moral Limits of the Criminal Law. Oxford: Oxford University Press.

Flathman, Richard E. 1987. The Philosophy and Politics of Freedom. Chicago: University of Chicago Press.

Fukuyama, Francis. 2002. Our Posthuman Future: Consequences of the Biotechnology Revolution. New York: Farrar, Straus, and Giroux.

Gray, John. 1989. Liberalisms: Essays in Political Philosophy. London and New York: Routledge.

—. 1993. Post-Liberalism: Studies in Political Thought. New York and London: Routledge.

Kim, Sungmoon. 2014. Confucian Democracy in East Asia: Theory and Practice. New York: Cambridge University Press.

- 2016. Public Reason Confucianism: Democratic Perfectionism and Constitutionalism in East Asia. New York: Cambridge University Press.

Kymlicka, Will. 1989. "Liberal Individualism and Liberal Neutrality." Ethics 99 (4): 883-905. 
Li, Zehou 李泽厚. 2008. Lunyu jindu 論語今讀 (Reading the Analects Today). Beijing: SDX Joint Publishing.

—. 2011. Zhexue gangyao 哲學綱要 (Outline of a Philosophy). Beijing: Peking University Press.

- 2012. Zhongguo zhexue ruhe dengchang? 中国哲学如何登场? (How Can Chinese Philosophy Go on Stage?). Shanghai: Yiwen chubanshe.

—. 2016. "A Response to Michael Sandel and Other Matters." Translated by Paul J. D'Ambrosio and Robert A. Carleo III. Philosophy East and West 66 (4): 1068-47.

—. 2017. "Lunlixue zai buzhu" 伦理学再补注 (Further Additional Comments on Ethics). Manuscript.

- 2018. The Origins of Chinese Thought: From Shamanism to Ritual Regulations and Humaneness. Translated by Robert A. Carleo III. Boston and Leiden: Brill.

MacIntyre, Alasdair. 1984. After Virtue: A Study in Moral Theory, sec. ed. Notre Dame, Indianapolis: University of Notre Dame Press.

Parfit, Derek. 2002. "What We Could Rationally Will." The Tanner Lectures on Human Values. http://tannerlectures.utah.edu/_documents/a-to-z/p/ parfit_2002.pdf.

Raz, Joseph. 1988. The Morality of Freedom. Oxford: Oxford University Press.

Rawls, John. 1999. A Theory of Justice, rev. ed. Cambridge, MA: The Belknap Press of Harvard University Press.

Scanlon, Thomas M. 2014. Being Realistic about Reasons. Oxford: Oxford University Press.

—. 2011. "How I am not a Kantian." In Derek Parfit, On What Matters, vol. 2, edited by Samuel Scheffler, 116-39. Oxford: Oxford University Press.

Taylor, Charles. (1979) 1985. "Atomism." In Philosophy and the Human Sciences: Philosophical Papers 2, 187-210. Cambridge, UK: Cambridge University Press. 